\title{
Social Entrepreneurs' Use of Fab Labs and 3D Printing in South Africa and Kenya
}

\section{Tobias Schonwetter}

Associate Professor, Department of Commercial Law, and Director, Intellectual Property Unit, Faculty of Law, University of Cape Town; and Co-Founding Director and Researcher, Open African Innovation Research (Open AIR) network

(iD https://orcid.org/0000-0002-7859-4465

\section{Bram Van Wiele}

Lecturer, University of Auckland Business School; Research Fellow, Intellectual Property Unit, Faculty of Law, University of Cape Town; and Researcher, Open African Innovation Research (Open AIR) network

(iD https://orcid.org/0000-0003-0911-6168

\begin{abstract}
This article outlines findings from a study in South Africa and Kenya that explored social entrepreneurs' use of fabrication laboratories (fab labs), and in particular fab lab 3D printing services, in order to advance their social innovations and enterprises. Based on interviews with representatives of fab lab initiatives and social enterprises, the study found strong linkages between social entrepreneurship and fab labs, and between social entrepreneurs and the use of $3 \mathrm{D}$ printing technology. However, it was also found that social entrepreneurs tend not to rely primarily on fab labs for access to $3 \mathrm{D}$ printers, preferring to buy and build their own printer units-a practice made cost-effective through the selection of low-cost, open source models. In respect of the computer-aided design (CAD) software used to design the files for $3 \mathrm{D}$ printing, it was found that social entrepreneurs prefer the stability and user-friendliness of proprietary $\mathrm{CAD}$ software, despite the cost implications. At the same time, it was found that social entrepreneurs frequently use free and open source CAD files available online, and that they seek, in turn, to share their designs on a free and open source basis.
\end{abstract}

\section{Keywords}

social entrepreneurship, social innovation, informal sector innovation, social enterprises, fabrication laboratories (fab labs), additive manufacturing, computer-aided design (CAD), 3D printing, collaboration, knowledge-sharing, knowledge appropriation, knowledge governance, maker movement, scalability, intellectual property (IP), openness, open source, high technology hubs, South Africa, Kenya 


\section{Acknowledgements}

The research for this article was carried out under the auspices of the Open African Innovation Research (Open AIR) network, which is a partnership between the University of Cape Town, the University of Johannesburg, The American University in Cairo, the Nigerian Institute of Advanced Legal Studies, Strathmore University in Nairobi, and the University of Ottawa. We acknowledge the support provided for this research by Open AIR, the Social Sciences and Humanities Research Council (SSHRC) of Canada, the International Development Research Centre (IDRC), the UK Department for International Development (DFID), the University of Cape Town, and our interviewees. This article draws on elements of a working paper (Schonwetter \& Van Wiele, 2018).

DOI: $\underline{\text { https://doi.org/10.23962/10539/30356 }}$

\section{Recommended citation}

Schonwetter, T., \& Van Wiele, B. (2020). Social entrepreneurs' use of fab labs and $3 \mathrm{D}$ printing in South Africa and Kenya.The African Journal of Information and Communication (AJIC), 26,1-24. https://doi.org/10.23962/10539/30356

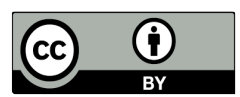

This article is licensed under a Creative Commons Attribution 4.0 International (CC BY 4.0) licence: https://creativecommons.org/licenses/by/4.0

\section{Introduction}

3D printing technology has been touted as revolutionising manufacturing and entrepreneurship, and, in African contexts, serving as a tool to help African nations, inter alia, overcome their "resource curse" (Mathers, 2015; Ortolani \& Di Bella, 2014) and "leapfrog" the industrial revolution (Jacobs, 2015; Mungai, 2015). One potentially vibrant field of application for 3D printing in Africa is the work of social entrepreneurs, i.e., application in support of those focusing their efforts on achieving positive societal impacts through enterprises targeting pressing social, economic, environmental, or cultural problems. According to one report, 3D printing in developing-world countries "could enable locally designed solutions for local problems, potentially bringing large benefits to these economies" (WIPO, 2015, p. 98).

In an effort to shed light on the degree to which $3 \mathrm{D}$ printing is relevant to the work and business models of social entrepreneurs in African settings, we conducted this study focusing on two modes of 3D printer access currently present in South Africa and Kenya: via fabrication laboratories (fab labs), and via the use of lowcost, locally made $3 \mathrm{D}$ printers. Our core data collection consisted of interviews with 
representatives of fab lab initiatives and social enterprises. The selection of South Africa and Kenya was based on the fact that these two countries are widely regarded as two of the Sub-Saharan African countries that are furthest down the road in terms of $3 \mathrm{D}$ printing initiatives. It is hoped that our findings, as presented in this article, represent a useful contribution to the emerging bodies of literature on the maker movement (of which fab labs are a part) and social entrepreneurship in African settings. While the study did not seek to develop new, or challenge existing, concepts of social innovation and social entrepreneurship on the continent, it was grounded in a recognition of the important roles they play on the continent.

\section{Research context}

\section{Social entrepreneurship}

According to Rivera-Santos et al. (2015),

[t]he African continent is characterized by serious social issues, which can become opportunities for business creation, combined with a lack of resources and poor governance, which are likely to present particular challenges for social entrepreneurs and enterprises. (Rivera-Santos et al., 2015, p. 76)

These observations concerning the links between social challenges and entrepreneurship in African countries form an important conceptual bedrock for this study. Even though social entrepreneurship is still a relatively new phenomenon in the available literature, there are already myriad existing definitions and conceptions of social entrepreneurship. Many of the initial definitions have been summarised and outlined by Abu-Saifan (2012) and Mair and Noboa (2003). Newer conceptions, found in Barnard (2019), Brindle and Layton (2017), Maseno and Wanyoike (2020), Nwuneli (2016), and Oriakhogba (2020), are particularly relevant to this study. These conceptions recognise the links between social challenges and entrepreneurship as observed by Rivera-Santos et al. (2015), and add valuable nuance through bridging the fields of social entrepreneurship and development, and emphasising the importance of context and local dynamics. Building on these nuanced frameworks, and at the same time recognising the limitations of one-size-fits-all definitions, we sought to adopt our own broad yet context-specific and development-oriented definition of social entrepreneurship to guide our identification of relevant enterprises and products.

In our definition, social entrepreneurs are: entrepreneurs who are primarily interested in achieving positive societal impacts through developing market-oriented innovative solutions to address (local) social needs and to solve pressing social, economic, environmental, or cultural problems. This definition draws on commonalities across the key definitions as compiled by Abu-Saifan (2012) and Mair and Noboa (2003), 
and also echoes elements concerning development and local contexts as suggested by Maseno and Wanyoike (2020), Barnard (2019) and Oriakhogba (2020). It is important to acknowledge, however, that social entrepreneurs' focus on social return does not preclude them from simultaneously seeking financial gain. On the contrary, blending the goal of profitability with achieving positive social impact is often a key characteristic of social entrepreneurship ventures, setting them apart from narrower non-profit projects.

\section{$3 D$ printing}

$3 \mathrm{D}$ printing, also known as additive manufacturing, refers to a class of technologies that physically construct objects by consecutively adding layers of material based on computer-aided design (CAD) files. These technologies allow for localised, decentralised production of myriad customised products without the need for expensive equipment and production lines. In a broader sense, 3D printing includes the process of creation, customisation, and mass dissemination of digital designs followed by the additive manufacturing of the underlying object. The result is that $3 \mathrm{D}$ printing not only requires access to hardware, but also manufacturing knowledge and $\mathrm{CAD}$ software literacy. The International Organization for Standardization (ISO) defines seven groups of technologies that currently make up additive manufacturing (ISO, 2015): material extrusion, vat polymerisation, material jetting, binder jetting, sheet lamination, powder bed fusion, and direct energy deposition.

In this study, we focused on the most common and recognisable form of 3D printing: material extrusion, which consists of building an object from the bottom up by selectively depositing layers of material at high temperatures, allowing the layers to cool and bond together. The process itself, its use of low-cost materials (commonly plastics), and its speed of production make it a preferred type of manufacturing for rapid prototyping and small-scale modelling or manufacturing (Lipson \& Kurman, 2013, p. 68). Basic material extrusion printing techniques allow only for the production of relatively simple products made out of plastic, and a number of technical limitations apply, concerning, for instance, size, resolution, accuracy, and the ability to print overhanging parts. That being said, basic 3D printing can facilitate quick and increasingly cost-effective local production of much-needed goods, thus empowering local actors and reducing reliance on imports and industrial-scale supply/value chains.

\section{$3 D$ printing, social innovation and social entrepreneurship}

Examples abound of 3D printing technology being used by social innovators and entrepreneurs for prototyping and end-product manufacturing in developing-world contexts, including African settings. Birtchnell and Hoyle (2014) demonstrate that $3 \mathrm{D}$ printing offers a wide range of applications that address social needs for users and communities in the developing world. The international 3D Printing for Development (3D4D) Challenge, in which entrants from around the Global South seek to 
produce the most scalable grassroots community action project involving $3 \mathrm{D}$ printing, illustrates the technology's use in the production of objects that can empower people in the developing world (3D4D, n.d.). In African settings, extrusion printers have been used for the localised and customised production of, inter alia, prosthetic fingers, prosthetic hands ("robohands") and prosthetic legs (Bashir, 2016; MakerBot, 2013), weather stations (Freitag, 2015; Walker, 2016), and medical equipment (Clarke, 2017).

While commercial hardware producers play an important role in the $3 \mathrm{D}$ printer market, the rapid rise in consumer-level 3D printers is in part attributable to the emergence of various open source 3D printer initiatives (Tech et al., 2016). The open source character of these printers generally provides for free access to the underlying blueprints, combined with the permission for third parties to freely use and adapt the designs. One of the best-known open source printers is the RepRap (see Figure 1 ), a largely self-reproducing open source $3 \mathrm{D}$ printer that has gained wide popularity among communities of researchers, hobbyists, and hackers (RepRap, n.d.). RepRap printers use the materials extrusion printing process and are able to manufacture many of their own components (Jones et al., 2011). (The name RepRap is derived from the printer's ability to function as a "replicating rapid" prototyper.) Currently there are over 60 different RepRap designs available online for free, under open licences (General Public Licence (GPL) or Creative Commons), and there are localised African RepRap printer models, including the RepRap Morgan (MolitchHou, 2013; RepRap, n.d.) and the RoboBeast (Krassenstein, 2014; MakerBot, 2013).

Figure 1: The first version of the RepRap printer, the RepRap 1.0 Darwin, developed in 2008

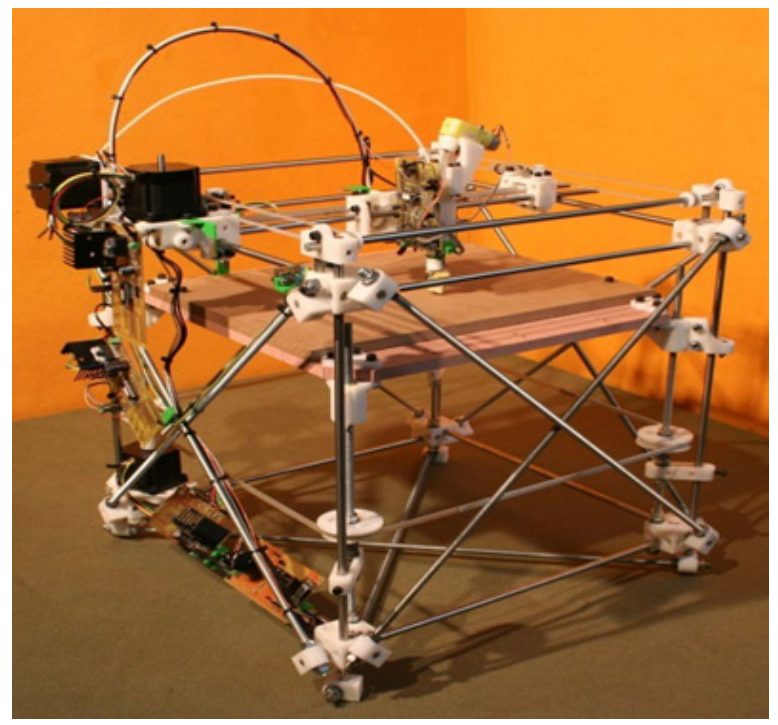

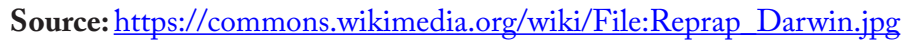




\section{Fab labs}

Several studies have looked at the work of fab labs as part of the broader maker movement in Africa (Armstrong et al., 2018; De Beer et al., 2017; ElHoussamy \& Rizk, 2018; Kraemer-Mbula \& Armstrong, 2017). Fab labs, as with makerspaces, hacklabs, tinker spaces, and other maker movement entities, typically offer to the public a range of digital fabrication tools, including $3 \mathrm{D}$ printers. In addition, they typically aim to create environments that facilitate innovative activity, entrepreneurship, and peer-to-peer learning.

The first fab lab was established in the early 2000s, in the US, at the Massachusetts Institute of Technology (MIT) as part of the outreach component of its Center for Bits and Atoms (CBA). Today, there are more than 1,700 fab labs around the world, in more than 100 countries (Fab Foundation, n.d.a). To officially qualify as an MIT-affiliated fab lab belonging to the MIT-established Fab Foundation, a lab must: (1) be open to the public (ideally free of charge); (2) support and subscribe to the Fab Charter; (3) provide a common set of tools and processes, based on the Fab Foundation's inventory; and (4) participate in the global fab lab network. According to the Fab Foundation, fab labs are "a global network of local labs, enabling invention by providing access to tools for digital fabrication" (CBA, 2012). According to the draft Fab Charter of 2012:

Fab labs are available as a community resource, offering open access for individuals as well as scheduled access for programs, [and while] [d]esigns and processes developed in fab labs can be protected and sold however an inventor chooses, [they] should remain available for individuals to use and learn from. (CBA, 2012)

The Fab Foundation has created an inventory of recommended hardware and materials to be deployed in a full fab lab. Fab lab core equipment typically includes $3 \mathrm{D}$ printers and a variety of cutting and milling machinery. The full list of recommended equipment is available on the Fab Foundation website (Fab Foundation, n.d.b). (It should be noted that there are many fab labs around the world that have adopted the fab lab name, or refer to themselves as fab labs, without joining the international Fab Foundation network. Thus, the term fab lab has taken on a generic meaning, and we use it in that way in this article.)

The fablabs.io website, which is the online social network of the international Fab Lab community, indicates that there are, as of mid-2020, fab lab initiatives in the following 24 African countries: Egypt, Libya, Tunisia, Morocco, Mauritania, Senegal, Mali, Burkina Faso, Côte d'Ivoire, Ghana, Togo, Benin, Nigeria, Chad, Cameroon, Democratic Republic of the Congo, Djibouti, Ethiopia, Kenya, Rwanda, Namibia, South Africa, Madagascar, and Réunion (Fablabs.io, n.d.). 


\section{Research design}

\section{Data collection and analysis}

Our study was qualitative, based on contextual data collected via desk research and primary data collected via interviews. The desk research consisted of reviewing relevant literature and the websites and social media pages of fab labs and social entrepreneurs in South Africa and Kenya. We identified existing fab labs in each country based on their current or past use of "fab lab" and their names or missions, with key guidance provided by the international Fab Lab network's listing of labs (Fablabs.io, n.d.). We also included three of South Africa's eKasi Labs, all of which incorporate fab lab elements. The interviews, which were semi-structured and guided by an interview protocol, were with representatives of (1) fab lab initiatives providing access to 3D printing; and (2) social enterprises using 3D printing technology. The interviewees at fab lab initiatives comprised individuals involved in lab management. The interviewees from social enterprises were founders and, in one case, the person currently running the enterprise. Our data analysis consisted of qualitative coding and categorising the content of the interview transcripts.

\section{Interview protocols}

Fab lab initiatives

The interview protocol for the interviewees representing fab lab initiatives covered matters of the initiatives' funding, structure, user access, users, uses, use of 3D printing technology, efforts to grow the user base, internal collaboration and knowledgesharing, knowledge appropriation, and scaling.

\section{Social enterprises}

The interview protocol for the interviewees representing social enterprises covered matters of the enterprises' origins, use of 3D printing technology, funding, internal collaboration and knowledge-sharing, knowledge appropriation, and scaling.

\section{Interview subjects}

The interviews consisted of:

- nine interviews with individuals in leadership positions at eight fab lab initiatives in South Africa and Kenya that provide access to 3D printing; and

- four interviewees with social enterprises in Kenya making use of 3D printers.

The eight fab lab initiatives from which interviewees were drawn are listed in Table 1. 
Table 1: Fab lab initiatives

\begin{tabular}{|c|c|c|c|}
\hline Initiative & $\begin{array}{l}\text { Year(s) of } \\
\text { Establish- } \\
\text { ment }\end{array}$ & Location(s) & URL \\
\hline $\begin{array}{l}\text { Bloemfontein FabLab } \\
\text { Central University of } \\
\text { Technology (CUT) }\end{array}$ & 2006 & $\begin{array}{l}\text { Bloemfontein, Free State } \\
\text { Province, South Africa }\end{array}$ & $\frac{\text { https://www.cut.ac.za/ }}{\underline{\text { fablab }}}$ \\
\hline $\begin{array}{c}\text { North West FabLab } \\
\text { North-West University } \\
\text { Potchefstroom Cam- } \\
\text { pus }\end{array}$ & 2007 & $\begin{array}{l}\text { Potchefstroom, North-West } \\
\text { Province, South Africa }\end{array}$ & $\begin{array}{l}\text { https://www.fablabs.io/ } \\
\text { labs/northwestuniversity }\end{array}$ \\
\hline $\begin{array}{c}\text { Sebokeng FabLab } \\
\text { Vaal University of } \\
\text { Technology (VUT) } \\
\text { Southern Gauteng } \\
\text { Science Park }\end{array}$ & 2014 & $\begin{array}{c}\text { Sebokeng, next to Vander- } \\
\text { bijlpark } \\
(60 \mathrm{~km} \text { south of Johannes- } \\
\text { burg) }\end{array}$ & $\frac{\underline{\text { https://www.vut.ac.za/ }}}{\underline{\text { fablab/ }}}$ \\
\hline $\begin{array}{c}\text { FabLab Nairobi } \\
\text { University of Nairobi } \\
\text { Upper Kabete Campus }\end{array}$ & 2009 & Nairobi & $\frac{\underline{\text { https://www.fablabs.io/ }}}{\text { labs/fablabnairobi }}$ \\
\hline $\begin{array}{l}\text { Limpopo FabLab } \\
\text { University of Limpopo } \\
\text { Turfloop Campus }\end{array}$ & 2009 & $\begin{array}{c}\text { Turfloop, } 32 \mathrm{~km} \text { from } \\
\text { Polokwane, Limpopo Prov- } \\
\text { ince, South Africa }\end{array}$ & $\frac{\underline{\text { https://www.fablabs.io/ }}}{\underline{\text { labs/limpopofablab }}}$ \\
\hline Ekurhuleni FabLabs & $2011-17$ & $\begin{array}{l}\text { Thokoza, Tembisa, Tsakane, } \\
\text { Duduza and Vosloorus } \\
\text { Ekurhuleni Municipality } \\
\text { (next to Johannesburg) }\end{array}$ & $\begin{array}{l}\text { https://www.fablabs.io/ } \\
\underline{\text { labs/ekurhulenifablabs }}\end{array}$ \\
\hline $\begin{array}{l}\text { CDI Product Support } \\
\text { Space } \\
\text { Craft and Design } \\
\text { Institute }(\mathrm{CDI})^{1}\end{array}$ & 2006 & Cape Town & $\begin{array}{l}\text { https://www.thecdi.org. } \\
\text { za/page/dev product }\end{array}$ \\
\hline eKasi Labs & 2014-16 & $\begin{array}{c}\text { Lynnwood (Pretoria), } \\
\text { Ga-Rankuwa (Pretoria } \\
\text { North) and Soweto (Johan- } \\
\text { nesburg) }\end{array}$ & $\frac{\text { https://www.facebook. }}{\underline{\text { com/ekasilabs/ }}}$ \\
\hline
\end{tabular}

1 The CDI Product Support Space includes the former Cape Town FabLab, which was launched in 2006 at the CDI (which at that time was called the Cape Craft and Design Institute (CCDI)). 
The social enterprises from which interviewees were drawn are listed in Table 2.

Table 2: Social enterprises

\begin{tabular}{|c|c|c|c|c|}
\hline Name & $\begin{array}{c}\text { Year of } \\
\text { Establishment }\end{array}$ & Location(s) & Products & URL \\
\hline $\begin{array}{c}\text { African Born } \\
\text { 3D Printing } \\
\text { (AB3D) }\end{array}$ & 2015 & Nairobi & $\begin{array}{l}\text { Low-cost open- } \\
\text { source 3D printers }\end{array}$ & $\frac{\text { https://www.ab3d. }}{\underline{\text { co.ke/ }}}$ \\
\hline Happy Feet & 2013 & Nairobi & $\begin{array}{l}\text { Customised shoes } \\
\text { for individuals with } \\
\text { foot deformities }\end{array}$ & $\begin{array}{l}\frac{\text { https://3dprint. }}{\text { com } / 25587 / \text { happy- }} \\
\frac{\text { feet-3d-printed- }}{\text { shoes/ }}\end{array}$ \\
\hline Artisan Hive & 2016 & Nairobi & $\begin{array}{l}\text { Headlamps, micro- } \\
\text { scopes }\end{array}$ & $\begin{array}{l}\frac{\text { https://www.linke- }}{\text { din.com/pulse/ar- }} \\
\frac{\text { tisan-hive-a-light- }}{\text { david-ismail/ }}\end{array}$ \\
\hline $\begin{array}{l}\text { Kijenzi (Med- } \\
\text { Tech Kijenzi at } \\
\text { the time of the } \\
\text { research) }\end{array}$ & 2014 & $\begin{array}{l}\text { Multiple } \\
\text { locations, } \\
\text { Kenya }\end{array}$ & $\begin{array}{l}\text { Medical equip- } \\
\text { ment }\end{array}$ & $\frac{\text { https://www.kijen- }}{\underline{\text { zi.com/ }}}$ \\
\hline
\end{tabular}

\section{Background: The fab lab initiatives and social enterprises studied}

\section{The fab lab initiatives}

\section{University-driven fab lab initiatives}

Bloemfontein FabLab and North West FabLab are both located on university campuses in urban environments. Bloemfontein FabLab, in the city of Bloemfontein, is located on the premises of the Central University of Technology (CUT). North West FabLab, in the city of Potchefstroom, is on the campus of North-West University, hosted by the Engineering Faculty. Both labs were initially established and funded by the South African Department of Science and Technology (DST), with funding later taken over by the universities.

Sebokeng FabLab, which is part of the Vaal University of Technology (VUT), is in fact not located on the VUT's main campus in the city of Vanderbijlpark. The lab is in VUT's Southern Gauteng Science and Technology Park, in the township of Sebokeng next to Vanderbijlpark. ${ }^{2}$

2 In the context of this research, "township" refers to "an urban or peri-urban area occupied predominantly by black South Africans and formerly officially designated for non-white occupation by apartheid segregation laws". (See http://www.oed.com/view/Entry/204077.) 
FabLab Nairobi is part of the University of Nairobi's Science and Technology Park, on the university's Upper Kabete Campus. It was initially on the university's City Campus, established with funding from the Ministry of Science and Technology, before the university took over the funding and moved it to Upper Kabete. In addition to its day-to-day funding by the university, the lab raises its own funds through providing services, including on-demand design and fabrication, and facilitating projects.

\section{University/government-driven fab lab initiative}

Limpopo FabLab is located at the Science Education Centre on the University of Limpopo's main campus in Turfloop, a township next to the city of Polokwane. Although physically located at the university, Limpopo FabLab is not run by the university. Its funding is provided by the university and by the Limpopo Province Department of Economic Development. Like the Bloemfontein and North West FabLabs, the Limpopo FabLab was originally established by the national government's DST.

\section{Government-driven fab lab initiatives}

The Ekurhuleni FabLabs initiative, funded and run by the Ekurhuleni Metropolitan Municipality next to Johannesburg, consists of five fab labs, in the Thokoza,Tembisa, Tsakane, Duduza, and Vosloorus townships.

The CDI Product Support Space is part of Cape Town's Craft and Design Institute (CDI) (formerly known as the Cape Craft and Design Institute (CCDI)). The CDI is a non-profit company funded by the City of Cape Town, the Western Cape Government, national government, and other supporters. The Product Support Space incorporates the equipment that was used by Cape Town FabLab before that lab's functions were taken over by the Product Support Space.

The eKasi Labs initiative is run by the Gauteng Province's Innovation Hub in Lynnwood, next to Pretoria. The three eKasi Labs we focused on, because they all incorporate fab lab elements, were the main eKasi Lab hub at the Innovation Hub, and eKasi Labs Ga-Rankuwa (in Ga-Rankuwa, 37 km north-west of Pretoria), and eKasi Lab Soweto (next to Johannesburg). The eKasi Labs, primarily funded and run by the Gauteng Government, are co-creation and innovation spaces linked to the Innovation Hub's enterprise incubation and commercialisation programmes.

\section{Fab lab users}

We found that fab labs are being used by a variety of different user groups, including entrepreneurs (among them social entrepreneurs), makers, hobbyists, high school learners, university students, and the general public. In the case of the CDI Product Support Space, users also include craft producers and designers. Two initiatives in 
particular, eKasi Labs and the CDI Product Support Space, are primarily used by entrepreneurs, including social entrepreneurs. The four labs driven by universitiesBloemfontein FabLab, North West FabLab, Sebokeng FabLab, and FabLab Nairobi-are predominantly used by students from their respective universities. There is also some use of these fab labs by secondary and/or tertiary educational institutions. For instance, some of Bloemfontein FabLab's users are students from a nearby high school and from the University of the Free State. The majority of the fab lab initiatives studied - all except Sebokeng FabLab and Ekurhuleni FabLabsreported that they are predominantly used by males. The majority of users across all of the fab labs are aged 35 or younger. In the case of Ekurhuleni FabLabs, the majority of users are schoolchildren between the ages of six and 16 .

\section{The social enterprises}

Our first point of contact in Kenya's social entrepreneurship sector was the aforementioned African Born 3D Printing (AB3D) enterprise, a manufacturer of low-cost, open source 3D printers. We then became aware of three additional social enterprises in Nairobi that use low-cost 3D printing technology, specifically printers derived from the aforementioned RepRap model.

$A B 3 D$

AB3D designs, produces, and sells 3D printers that are made from electronic waste and locally available materials and sell for a fraction of the price of commercially available machines. Most of the electric and electronic materials, such as wires, motors, and power supplies, are collected from a local e-waste centre. Other components are either produced by local craftsmen or $3 \mathrm{D}$-printed by $\mathrm{AB} 3 \mathrm{D}$, using their own machines. In addition to their core activity of providing low-cost 3D printers, they also provide printing services, education, and training, all based on 3D printers. Both of AB3D's co-founders, Roy Ombatti and Karl Heinz Tondo, are long-standing social innovators.

\section{Happy Feet}

AB3D's co-founder Ombatti's intensive immersion in the use of 3D printing has come about through his work on the Happy Feet social enterprise. Happy Feet uses 3D printers to manufacture low-cost, customised shoes for people with deformed feet. Such deformities are the result of infestation by chigoe fleas (jiggers), an ailment that is particularly prevalent in Kenya's impoverished areas. The project emerged from the international 3D for Development Challenge (3D4D Challenge), in which the UK-based charity TechforTrade (n.d.) donated a 3D printer to FabLab Nairobi and invited its users to submit ideas. Having volunteered with an NGO in the field of sand flea infestation, Ombatti decided, for the 3D4D Challenge, to create the prototype for the aforementioned customised shoe. Working with colleagues at FabLab Nairobi, he developed the Happy Feet prototype, which was a finalist in the 3D4D Challenge (Goehrke, 2014). 


\section{Artisan Hive}

AB3D's other co-founder, Tondo, founded Artisan Hive, which seeks to create designs and sustainable business models for 3D-printed social innovations that solve or mitigate problems in Kenyan communities. Artisan Hive has developed a 3D-printed headlamp made from locally available components, which aims to solve the problem of insufficient lighting for local fishermen working in morning or evening darkness. In the future, Artisan Hive aims to train and equip local fishermen so that they themselves can produce and sell the product at a profit. Artisan Hive also 3D-prints microscopes. It does its 3D printing, with low-cost $3 \mathrm{D}$ printers that it owns, at FabLab Nairobi. Its eventual goal is to set up community-based 3D printing kiosks to bring additive manufacturing to new potential users. Through education and training in 3D printing, Artisan Hive also aims to have "foot soldiers" who can go to communities to solve everyday problems.

\section{Kijenzi}

The Kijenzi project (known as "MedTech Kijenzi" at the time of the data collection) is using $3 \mathrm{D}$ printing to help mitigate equipment supply shortages faced by rural medical facilities in Kenya. The project also aims to train clinic personnel in the use of 3D printing technology so that they can engage in equipment replacement more efficiently and independently. The project started in 2014, and the project team comprises professors, engineers, students, and makers. In its initial phase, the project assessed eight hospitals in Kenya to establish which items were in store, which needed replacement, or which were difficult to obtain. Thereafter, the team established to what extent these items could be produced locally by using 3D printing technology. Examples of products it prints include an aperture adjustment knob, a blood pressure cuff tubing coupler, a finger clamp pulse oximeter, and an incubator door hatch (Kijenzi, n.d.).

\section{Findings}

We now present findings in terms of five of the most prominent themes identified in the interview data, as follows:

- fab lab accessibility for users;

- social entrepreneurs' use of fab labs and 3D printers;

- $3 \mathrm{D}$ printing hardware and software;

- knowledge-sharing and knowledge appropriation; and

- approaches to scaling.

\section{Fab lab accessibility for users}

In the interview data, we were able to establish three main factors that play a role in determining the lab's degree of accessibility to users seeking to make use of 3D printers: openness to the general public, fees, and location. 


\section{Openness to general public}

We found that all but one of the fab lab initiatives are open for use by the general public. The exception is the eKasi Labs initiative, whose labs in Lynnwood, GaRankuwa and Soweto are open only to those who are part of the eKasi incubator programme based at the Innovation Hub. However, we found that the eKasi labs were considering opening their doors to the general public in the future.

Fees

FabLab Nairobi charges fees on a case-by-case basis, with individual users typically charged a membership fee, except when the use is for mere experimentation purposes, provided the production work is not extensive. Start-ups and established companies are charged fees, including membership fees and additional fees based on their individual requirements. None of the South African fab lab initiatives studied charges general membership fees for all users. Limpopo FabLab charges a small fee to students using the lab as part of their coursework. Bloemfontein FabLab, North West FabLab, and Sebokeng FabLab charge their users for machine time and materials used. Limpopo FabLab charges fees to users who exceed an allocated maximum amount of use. The labs' charges are generally set at low levels, aimed at covering operating costs. But even small fees can present an access barrier for some (potential) users. As one interviewee put it:

[...] you've got a lot of people coming from streets, and you've also got the school kids and the community also coming in. It's a bit difficult that you have to charge these people because, essentially, they don't have a lot of skills and you are training them and you're showing them how everything works. [...] these people are coming to you to acquire skills and they don't have funding.

\section{Location}

We found that location is a potential barrier for accessing fab labs, with three factors playing key roles: availability of transport to and from the lab, physical barriers to access at labs located at universities, and bias. Representatives from fab labs located in urban areas indicated that transport to and from the lab can be a major problem for those who reside outside these urban areas. Similarly, an interviewee from Limpopo FabLab reported that its location in the Turfloop township near Polokwane presents an access barrier for users from rural areas. An interviewee from North West FabLab, located at North-West University's Potchefstroom campus, shared with us their perception that people from the community often find it cumbersome and difficult to access university premises. 
Similarly, FabLab Nairobi interviewees raised the concern that the fab lab's location on a university campus might negatively affect the use of these facilities by the general public. It was pointed out that those who are not affiliated with university campuses are usually unfamiliar with, and in some cases intimidated by, the university's access procedures. Another concern raised was that FabLab Nairobi is now located at the Upper Kabete campus, which houses the College of Agriculture and Veterinary Sciences-yet the typical users of the fab lab are engineering students. (The fab lab was initially housed in the School of Engineering on the University of Nairobi's City Campus.) Engineering students might now be reluctant to commute to another campus, while those working or studying at the lab's current campus typically did not use the fab lab's facilities—at least not until now.

Several of the fab lab interviewees said that biases against a fab lab's location can also present an access barrier, e.g., biases based on assumptions about the lab's users and the lab's safety. For instance, interviewees from fab labs located in townships indicated that people from the adjacent cities do not typically use the labs, and that location bias probably plays a role in this. In the words of interviewee 4 from Ekurhuleni FabLabs, "the one hindrance factor that we have to look at [is that] people are sometimes a bit sceptical [and] afraid to get into the township to use the lab".

\section{Social entrepreneurs' use of fab labs and $3 D$ printers}

Several of the fab labs - Limpopo FabLab, CDI Product Support Space, Bloemfontein FabLab, Ekurhuleni FabLabs, North West FabLab, Sebokeng FabLab, and FabLab Nairobi-indicated that their facilities are being used for social entrepreneurial activities. Notably, however, only North West FabLab and Limpopo FabLab in South Africa, and FabLab Nairobi in Kenya, have hosted 3D printing work by social entrepreneurs. At North West FabLab, 3D-printed components have been combined with plexiglass in order to create scale models of potential adaptations to used shipping containers so that they can house toilets. At Limpopo FabLab, scale 3D models of toilets were used to pitch ideas to the municipality. FabLab Nairobi is the only fab lab that had, at the time of our research, seen end-product manufacturing of social entrepreneurial goods, via the work of the Artisan Hive project it houses. As described earlier, Artisan Hive uses the physical space of the Nairobi FabLab to run its own low-cost 3D printers.

In our interactions with social entrepreneurs in Kenya, we learned that while social entrepreneurs make only limited use of the fab labs and their 3D printers to carry out their social entrepreneurial activities, many do use the labs, or other makerspaces, to acquaint themselves with $3 \mathrm{D}$ printing technology. And, in some cases, fab labs play advisory roles for social enterprises, or serve as backup facilities when an enterprise's $3 \mathrm{D}$ printer breaks down. 
While the link between social entrepreneurship and the use of fab labs to gain access to $3 \mathrm{D}$ printing technologies is, apparently, not as pronounced as we initially expected, we did find a close link between social entrepreneurship and the availability of affordable and openly accessible 3D printing technology. As described above, 3D printers are the primary manufacturing tool for Artisan Hive, which resorts to other means of manufacturing only if the production cannot be done with $3 \mathrm{D}$ printing. In the words of interviewee 11 of $\mathrm{AB} 3 \mathrm{D}$ and Artisan Hive, 3D printing is "the easiest and cheapest way". In using 3D printing as the main production method, Artisan Hive is less dependent on supply chains, and the investment cost in a printer repays itself in a short time period. For instance, with respect to the Artisan Hive's plan to support local fishermen to produce and use 3D-printed headlamps, an initial investment by the fishermen in two low-cost 3D printers could potentially repay itself in a month. Similarly, according to interviewee 8 of AB3D and Happy Feet:

You give me the printer and we make the shoes and it's just that simple. Change people's lives. It's very direct. As opposed to, perhaps, what if we didn't have $3 \mathrm{D}$ printers at all? Forget even the expensive ones. This project would never proceed because the conventional manufacturing techniques would have involved perhaps injection moulding, which for a certain number is super, super expensive.

\section{D printing hardware and software}

\section{Hardware}

All of the fab labs studied have at least one proprietary material extrusion 3D printer. The CDI Product Support Space in Cape Town had, at the time of the research, four such printers, and Sebokeng FabLab had eight. The high number of 3D printers available at Sebokeng FabLab is due to the fact that the lab has links to its university's (VUT's) Idea to Product (I2P) initiative, situated in the same science park. North West FabLab also has an open source RepRap printer, and the 3D printers being used by Artisan Hive at FabLab Nairobi are all open source.

\section{Software}

Most of the fab labs provide access to both open source and proprietary software for generating the CAD file necessary for $3 \mathrm{D}$ printing. The majority (all but two) of the labs indicated a preference for proprietary CAD software, on the grounds of the software's apparent user-friendliness, conformity with industry standards, and absence of bugs. The two exceptions were the CDI Product Support Space and Limpopo FabLab, both of which mainly use - and encourage the use of - open source software, on the grounds that their users can get free copies for use outside the fab lab facilities. At the same time, both the CDI Product Support Space and Limpopo FabLab continue to also provide access to proprietary software at their labs. 
One lab, Sebokeng FabLab, employs a "use appropriate approach" (interviewee 5) when it comes to software. For introduction to, and training in, CAD software, the lab was, at the time of the research, using Autodesk 123Design, under a freemium licence (i.e., a licence allowing free use of basic features, with a fee required for access to the premium version with additional functionality). Students are able to get a two-year free licence for Autodesk 123D when registering on the Autodesk website. In addition, the lab provides access to Autodesk Fusion 360. The lab also delivers commissioned work for clients through the use of more expensive proprietary software such as Solidworks and Solid Edge.

We found that the social entrepreneurs interviewed generally prefer and use proprietary CAD software, due to its perceived ease of use and reliability.

\section{Knowledge-sharing and knowledge appropriation}

We found that while all the fab labs offer some kind of formalised training-typically through seminars, workshops, and one-one-one training-informal peer-to-peer learning also plays a critical role. All fab labs encourage peer-to-peer learning, where users teach one another how to improve designs and use machinery. For instance, while the participants in the eKasi programme received training on the machines at the beginning of each programme, users who join after a programme has begun need to catch up, and that knowledge gap is filled through peer learning from more experienced users. Another example is Limpopo FabLab, which has a tutoring system in place whereby experienced users teach and assist new users.

Most fab lab interviewees reported that issues around formalised knowledge appropriation-e.g., in the form of a proposed non-disclosure agreement (NDA) or a desire to secure intellectual property (IP) rights—arise regularly. Most of the labs have been asked by a user to sign an NDA or a memorandum of understanding (MOU). The labs have differing approaches to handling such requests.

The CDI Product Support Space does not sign NDAs, on the grounds that the space is an open access facility where non-disclosure cannot be guaranteed. Bloemfontein FabLab provides and uses a standardised NDA form. The eKasi Labs programme offers its users consultations with the Innovation Hub's legal advisors on IP matters. Sebokeng FabLab refers users seeking IP protection to the university's (VUT's) Enterprise Development Unit. Users of FabLab Nairobi are given access to the University of Nairobi Intellectual Property Management Office. None of the fab labs asserts any claims on innovations resulting from the use of their facilities. The Ekurhuleni FabLabs initiative does, however, require express recognition if a product is developed using its facilities. 
Interviewees at Limpopo FabLab and FabLab Nairobi stated that the sharing of ideas is essential for product development and market success, and that users who are reluctant to share typically do not successfully complete their projects. According to interviewee 6 of Limpopo FabLab:

What I have discovered is that those that do have this problem of opening up their projects and their ideas have always had a problem of actually never completing their projects. And I've also done follow-ups just to check how far they would be. But none of them has ever succeeded with getting a prototype and $[\ldots]$ moving forward.

In the words of interviewee 10 at FabLab Nairobi:

So we do get those people who really want to keep it to themselves. They think they have a brilliant idea. But the problem is they're not designers themselves, so they don't know anything about the drawbacks or loopholes of the designs. That's why we invite you to share your idea with one or two people to further the design, not just keep it to yourself. Because most of the people who have come and told me we need to sign an MOU—all their products have problems.

And interviewee 9 at FabLab Nairobi stated:

It's the only way ideas are improved. But there's the culture [of] 'I have an idea-it's mine. I don't want to share it. I want to get rich and sell it tomorrow.' But it usually doesn't work that way. At least from being in fab labs, that's what we've learned. You need all these people that are around you to give you different ideas. You need people around you to give you different networks. There are people relevant for your idea to go out. So I think open sourcing most of our ideas is something that needs to be encouraged a lot, especially in an African set-up.

All four of the social entrepreneurial projects investigated are generally committed to the open sharing of their designs and other data. Kijenzi is dedicated to open source, and, at the time of the research, aimed to eventually share its data, printer, and object designs through open source licensing. At ABD3D and its spin-off projects, many of the designs produced are based on available open source designs. For instance, Artisan Hive's 3D-printed microscope is based on an open-licensed design by Richard Bowman from the Department of Physics at the University of Bath in the UK. 
According to interviewee 11 of $\mathrm{AB} 3 \mathrm{D}$ and Artisan Hive:

As of now we don't really focus on [knowledge appropriation] because we want first of all to open a framework to just encourage creativity and design in our communities. [...] We believe in open collaboration [...]. On our website you $[\ldots]$ have the files for anything we make. Anything we make is open source.

This said, Artisan Hive may consider looking into a formal form of IP protection at a later stage, once people have been widely exposed to their designs and creative efforts.

Interviewee 8 of AB3D and Happy Feet said that "it's ethical, to be fair and give back". And in the context of his work with $\mathrm{AB} 3 \mathrm{D}$, he is in favour of sharing ideas, and widely shares his technical knowledge through teaching and other activities. However, with respect to the Happy Feet project, he feels the need for some form of limit on the openness of the sharing. He would ideally like to have some form of formal IP protection in order to preserve the original vision for the project:

It's less that others cannot copy, but more so that my initial vision [for] why I created it can remain as it is. I wouldn't want someone with more muscle and more money to come in, take it up and perhaps make more money out of that and exploit the people. I want to retain that control, or initial vision as to why we started this. It's less to block out those who want to copy, but more to protect its original mission and see it through.

\section{Approaches to scaling ${ }^{3}$}

For the social entrepreneurs we interviewed, the issue of scaling is mainly perceived as being linked to becoming (more) sustainable, and increasing the impact of their work and products. For AB3D, scaling up will ideally include a broader offering. Interviewee 8 of AB3D and Happy Feet envisions developing an umbrella platform offering health care, educational, and agricultural hardware solutions. Such a platform would include alternative manufacturing methods to supplement current offerings, including the use of computer numerical control (CNC) machines such as laser cutters. AB3D would aim to build these machines themselves, making them low-cost. "That is my vision of scaling [for AB3D]: Touching more lives, but not just with one thing, $[\ldots]$ with different things", interviewee 8 said.

For Artisan Hive, part of its future vision of scaling, if and when external funding becomes available, is a desire to make $3 \mathrm{D}$ printers, knowledge, and locally relevant

3 For an in-depth treatment of approaches to innovation-scaling by makerspaces and other knowledge-based enterprises in African settings, see Open AIR (2020), Scaling Innovation: How Open Collaborative Models Help Scale African Knowledge-Based Enterprises. 
products more available in the remote areas of Kenya. (The project was, at the time of the research, exclusively funded by its founder, and external funding was considered essential for it to scale up.) In the short term, in the absence of external funding, Artisan Hive aims to make its projects more sustainable by offering training for a fee. At the same time, however, Artisan Hive is committed to keeping its designs open and free to access and use, as its core aim, in the words of interviewee 11, is "to inspire and create".

\section{Analysis and conclusions}

A number of notable dimensions, including some conflicts and contradictions, emerge from the research. A core finding is the social entrepreneurs' preference for open source 3D printers-because their speed and quality is often equal or superior to the performance of proprietary $3 \mathrm{D}$ printers. The fact that these printers can be more easily repaired locally, and thus cheaply, is also beneficial. And the designs the social entrepreneurs use tend to be free and open source CAD files created by third parties, with the social entrepreneurs publicly sharing back the designs they generate (or planning to share back in the future, in the case of Kijenzi), on a free and open source basis. However, the social entrepreneurs' preference for open source hardware and open approaches to using and sharing designs is coupled with a preference for using proprietary software when designing and producing $\mathrm{CAD}$ files. This preference for proprietary CAD software, even with its higher cost, is a result of its perceived greater user-friendliness and reliability. Thus, rather than opting for openness in all areas and at all costs, the social entrepreneurs also base their decisions on useability.

Another key finding is that while the fab labs studied do host numerous social entrepreneurs, most of these social entrepreneurs do not use 3D printers provided by the fab labs. The social entrepreneurs studied who need to use 3D printers are more likely to purchase or build their own. This can be explained by the fact that the social entrepreneurs in this study are utilising $3 \mathrm{D}$ printing not to prototype, but rather to execute the products that are core to their social enterprises. This type of manufacturing does not fit well with the core stated objectives of most fab labs, which are aimed at facilitating product development rather than large-scale production.

Where fab labs apparently do play a crucial role for the social entrepreneurs studied is in providing space for knowledge-sharing. Evidence was found of social entrepreneurs having previously worked in fab labs and other maker spaces, where they had gained $3 \mathrm{D}$ printing knowledge and developed the expertise necessary to run their enterprises and develop their products. This is in line with the notion that an open approach to sharing of ideas and knowledge is crucial to the value of these spaces. At the same time, however, some evidence was found of social entrepreneurs adopting protective approaches, within these labs, to their products. Thus, as with their software choices, the principle of openness is not absolute in social entrepreneurs' choices when making use of fab labs. This non-absolute adherence to openness also apparently extends 
to the studied social entrepreneurs' perceptions of the potential value of formalised intellectual property (IP) protections. While the social entrepreneurs appear to be, at present, prioritising social value over commodification, formal modes of IP protection may come more into play in the future, as the entrepreneurs explore available options for sustaining and scaling their businesses.

\section{References}

3D Printing for Development Challenge (3D4D Challenge). (n.d.). https://www.facebook. com/3D4Dchallenge

Abu-Saifan, S. (2012). Social entrepreneurship: Definition and boundaries. Technology Innovation Management Review, February, 22-27. https://doi.org/10.22215/timreview/523

African Born 3D Printing (AB3D). (n.d.). https://www.ab3d.co.ke/

Armstrong, C., De Beer, J., Kraemer-Mbula, E., \& Ellis, M. (2018). Institutionalisation and informal innovation in South African maker communities. Journal of Peer Production (JoPP), 12(1), 14-42. https://peerproduction.net/wp-content/uploads/2018/07/ jopp issue12 vol1of3.pdf

Ashoka. (n.d.). Social entrepreneurship. https://www.ashoka.org/en/focus/socialentrepreneurship

Barnard, H. (2019). From the editor: The social side of international business policy - mapping social entrepreneurship in South Africa. Journal of International Business Policy, 2, 1-8. https://doi.org/10.1057/s42214-018-00018-1

Bashir, O. (2016, May 14). How 3D prosthetics change lives in Pakistan. Dawn. https://www.dawn.com/news/1254750

Birtchnell, T., \& Hoyle, W. (2014). 3D printing for development in the Global South: The 3D4D challenge. Palgrave Macmillan. https://doi.org/10.1057/9781137365668 2

Bloemfontein Fablab. (n.d.). https://www.cut.ac.za/fablab

Bornstein, D. (1998, January). Changing the world on a shoestring. The Atlantic. https:// www.theatlantic.com/magazine/archive/1998/01/changing-the-world-on-ashoestring $/ 377042$

Brinkerhoff, P. C. (2009). Mission-based management: Leading your non-for-profit in the 21st century (3rd ed.). John Wiley \& Sons.

Brindle, M., \& Layton, R. (2017). Social entrepreneurship for development: A business model. Routledge. https://doi.org/10.4324/9781315646763

Canadian Centre for Social Entrepreneurship. (2001). Social entrepreneurship discussion paper no. 1. https://citeseerx.ist.psu.edu/viewdoc/download?doi=10.1.1.194.4683\&rep=rep1\&type=pdf

CDI Product Support Space. (n.d.). https://www.thecdi.org.za/page/dev product

Center for Bits and Atoms (CBA). (2012). The Fab Charter. Draft document. https://fab. cba.mit.edu/about/charter/

Clarke, C. (2017, February 17). 3D printing to redefine the medical supply chain in Africa. 3D Printing Industry. https://3dprintingindustry.com/news/3d-printing-redefinemedical-supply-chain-africa-105989 
Dacin, P. A., Dacin, M. T., \& Matear, M. (2010). Social entrepreneurship: Why we don't need a new theory and how we move forward from here. Academy of Management Perspectives, 24(3), 37-57. https://doi.org/10.5465/amp.24.3.37

Dana, L. P., Ratten, V., \& Honyenuga, B. Q. (Eds.). (2018). African Entrepreneurship: Challenges and opportunities for doing business. Springer. https://doi.org/10.1007/978-3-319-73700-3

De Beer, D., Du Preez, W., Greyling, H., Prinsloo, F., Sciammarella, F., Trollip, N., \& Vermeulen, M. (2016). A South African additive manufacturing strategy. https://www. dst.gov.za/images/2018/Additive\%20Manufacturing\%20Strategy.pdf

De Beer, J., Armstrong, C., Ellis, M., \& Kraemer- Mbula, E. (2017). A scan of South Africa's maker movement. Open AIR Working Paper 9. Open African Innovation Research (Open AIR) network. https://openair.africa/a-scan-of-south-africas-makermovement/

De Beer,J., Oguamanam, C., \& Schonwetter, T. (2013). Innovation, intellectual property and development narratives in Africa. In J. De Beer, C. Armstrong, C. Oguamanam, \& T. Schonwetter (Eds.), Innovation and intellectual property: Collaborative dynamics in Africa (pp. 1-31). UCT Press.

Dees, J. G. (1998). The meaning of "social entrepreneurship". Research Paper. https://centers. fuqua.duke.edu/case/wp-content/uploads/sites/7/2015/03/Article_Dees MeaningofSocialEntrepreneurship 2001.pdf

eKasi Labs. (n.d.). https://www.facebook.com/ekasilabs/

Ekurhuleni Fablabs. (n.d.). https://www.fablabs.io/labs/ekurhulenifablabs

ElHoussamy, N., \& Rizk, N. (2018). The maker movement across North Africa. Open AIR Working Paper 17. Open African Innovation Research (Open AIR) network. https://openair.africa/the-maker-movement-across-north-africa/

Fab Foundation. (n.d.a). [Website]. https://fabfoundation.org/

Fab Foundation. (n.d.b). Fab lab resources. https://fabfoundation.org/globalcommunity/\#resources-fablabs

Fablabs.io. (n.d.). Labs. https://www.fablabs.io/labs

FabLab Nairobi. (n.d.). https://www.fablabs.io/labs/fablabnairobi

Fowler, A. (2000). NGDOs as a moment in history: Beyond aid to social entrepreneurship or civic innovation? Third World Quarterly, 21(4), 637-654.

https://doi.org/10.1080/713701063

Freitag, H. (2015, March 16). How 3D printing can help save lives. [Blog post]. https://blog. usaid.gov/2015/03/how-3d-printing-can-help-save-lives

Goehrke, S. A. (2014, November 19). Engineering students design "Happy Feet," 3D printed shoes for Kenyans afflicted by jigger infection. https://3dprint.com/25587/happyfeet-3d-printed-shoes/

Hand, M. (2016, May 24). The research gap in social entrepreneurship. Stanford Social Innovation Review. https://ssir.org/articles/entry/the research gap in social entrepreneurship

Hibbert, S. A., Hogg, G., \& Quinn, T. (2002). Consumer response to social entrepreneurship: The case of the Big Issue in Scotland. International Journal of Nonprofit and Voluntary Sector Marketing, 7(3), 288-301. https://doi.org/10.1002/nvsm.186 
Institute for Social Entrepreneurs. (n.d.). Social enterprise terminology. https://www. socialent.org/social enterprise terminology.htm

International Organisation for Standardization (ISO). (2015). ISO/ASTM 52900:2015 (ASTM F2792): Additive manufacturing - general principles - terminology. https://www.iso.org/standard/69669.html

Ismail, D. (2018). Artisan Hive: A-light. https://www.linkedin.com/pulse/artisan-hive-alight-david-ismail/

Jacobs, S. (2015, March 13). A 3D revolution in Africa? This is Africa. https://www. thisisafricaonline.com/Business/A-3D-revolution-in-Africa

Johnson, R. B., Onwuegbuzie A. J., \& Turner, L. A. (2007). Towards a definition of mixed method research. Journal of Mixed Methods Research, 1(2), 112-133. https://doi.org/10.1177/1558689806298224

Jones, R., Haufe, P., Sells, E., Iravani, P., Olliver, V., Palmer, C., \& Bowyer, A. (2011). RepRap - the replicating rapid prototyper. Robotica, 29(1), 177-191.

https://doi.org/10.1017/S026357471000069X

Kijenzi. (n.d.). Catalog. https://www.kijenzi.com/catalog/\#spare-parts

Kraemer-Mbula, E., \& Armstrong, C. (2017). The maker movement in Gauteng Province, South Africa. Open AIR Working Paper No. 6. Open African Innovation Research (Open AIR) network. https://openair.africa/the-maker-movement-in-gautengprovince-south-africa

Krassenstein, B. (2014, February 15). RoboBeast 3D printer unveiled, toughest printer by far. 3DPrint.com. https://3dprint.com/1063/robobeast-3d-printer-unveiled-toughestprinter-by-far

Leadbeater, C. (1997). The rise of the social entrepreneur. Demos. https://www.demos.co.uk/ files/theriseofthesocialentrepreneur.pdf

Leyronas, S., Liotard, I., \& Prié, G. (2018, July 4). How fab labs help meet digital challenges in Africa. The Conversation. https://theconversation.com/how-fab-labs-help-meetdigital-challenges-in-africa-99202

Limpopo Fablab. (n.d.). https://www.fablabs.io/labs/limpopofablab

Lipson, H., \& Kurman, M. (2013). Fabricated: The new world of 3D printing. John Wiley \& Sons.

Mair, J., \& Noboa, E. (2003). Social entrepreneurship: How intentions to create social enterprise get formed. IESE Working Paper No. D/521. IESE Business School. https://dx.doi.org/10.2139/ssrn.462283

Mair,J., \& Noboa,E.(2006). Social entrepreneurship: How intentions to create a social venture are formed. In J. Mair, J. Robinson, \& K. Hockerts (Eds.), Social entrepreneurship (pp. 121-135). Palgrave Macmillan. https://doi.org/10.1057/9780230625655 8

Mahajan, S. (Ed.). (2014). Economics of South African townships: Special focus on Diepsloot. World Bank. https://doi.org/10.1596/978-1-4648-0301-7

MakerBot. (2013, March 22). Mechanical hands from a MakerBot: The magic of Robohand. https://www.makerbot.com/stories/engineering/robohand

MakerBot. (2014, January 30). MakerBot stories: Project Daniel takes Robohand to Sudan. https://www.makerbot.com/media-center/2014/01/30/project-daniel-takesrobohand-sudan 
Maker Station. (n.d.). [Website]. https://makerstation.co.za/i2plab

Maseno, M., \& Wanyoike, C. (2020). Social entrepreneurship as mechanisms for social transformation and social impact in East Africa: An exploratory case study perspective. Journal of Social Entrepreneurship.

https://doi.org/10.1080/19420676.2020.1755348

Mathers, I. (2015, August 17). 3D printing can revolutionise emergency healthcare. SciDev. Net. https://www.scidev.net/global/design/multimedia/3d-printing-emergencyhealthcare-haiti-maternity.html

Matthews, K. (2015, May 29). Disaster relief in three dimensions: Medical 3D printing in Haiti. 3DPrint.com. https://3dprint.com/68527/medical-3d-printing-in-haiti/

Molitch-Hou, M. (2013, June 3). RepRap Morgan in it natural habitat. 3D Printing Industry. https://3dprintingindustry.com/news/reprap-morgan-in-its-natural-habitat-12341

Mphuthi, L. (2013). Fab lab, a technology transfer platform for technical empowerment through science and technology education: A South African Fab labs impact evaluation. Master's thesis, Da Vinci Institute, Modderfontein, South Africa.

Mungai, C. (2015, August 8). "Guerrilla manufacturing": This 3D printing thing might just be Africa’s industrial magic wand. Mail \& Guardian.

North West Fablab. (n.d.). https://www.fablabs.io/labs/northwestuniversity

Nwuneli, N. O. (2016). Social innovation in Africa: A practical guide for scaling impact. Routledge. https://doi.org/10.4324/9781315646190

Open African Innovation Research (Open AIR). (2020). Scaling innovation: How open collaborative models help scale Africa's knowledge-based enterprises. https://openair. africa/scaling-innovation-how-open-collaborative-models-help-scale-africasknowledge-based-enterprises

Oriakhogba, D. O. (2020). Empowering rural women crafters in KwaZulu-Natal: The dynamics of intellectual property, traditional cultural expressions, innovation and social entrepreneurship. South African Law Journal, 137(1), 145-172.

Ortolani, G., \& Di Bella, P. (2014, 20 January). Building low-cost tools to bridge the digital divide. SciDev.Net. https://www.scidev.net/global/digital-divide/multimedia/ building-low-cost-tools-to-bridge-the-digital-divide.htm

RepRap. (n.d.). RepRap options. https://reprap.org/wiki/RepRap Options

RepRap Morgan. (n.d.). https://reprap.org/wiki/RepRap

Rivera-Santos, M., Holt, D., Littlewood, D., \& Kolk, A. (2015). Social entrepreneurship in Sub-Saharan Africa. Academy of Management Perspectives, 29(1), 72-91.

https://doi.org/10.5465/amp.2013.0128

SA FabLab. (n.d.). Welcome to SA FabLab. https://www.fab lab.co.za

Santos, F. M. (2012). A positive theory of social entrepreneurship. Journal of Business Ethics, 111(3), 335-351. https://doi.org/10.1007/s10551-012-1413-4

Schrock, A. R. (2014). "Education in disguise": Culture of a hacker and maker space. InterActions: UCLA Journal of Education and Information Studies, 10(1). https://escholarship.org/uc/item/0js1n1qg

Schonwetter, T., \& Van Wiele, B. (2018). 3D printing: Enabler of social entrepreneurship in Africa? The roles of FabLabs and low-cost 3D printers. Open AIR Working Paper 18. Open African Innovation Research (Open AIR) network. 
TechforTrade. (n.d.). [Website]. https://www.techfortrade.org

Tech, R., Ferdinand, J.-P., \& Dopfer, M. (2016). Open source hardware startups and their communities - the case of desktop 3D printing. In J.-P. Ferdinand, U. Petschow, \& S. Dickel (Eds.), The decentralized and networked future of value creation (pp. 129146). Springer. https://doi.org/10.1007/978-3-319-31686-4_7

Thompson, J., Alvy, G., \& Lees, A. (2000). Social entrepreneurship - a new look at the people and the potential. Management Decision, 38(5), 328-338.

https://doi.org/10.1108/00251740010340517

Troxler, P. (2016). Fabrication laboratories (fab labs). In J.-P. Ferdinand, U. Petschow, \& S. Dickel (Eds.), The decentralised and networked future of value creation (pp. 109-128). Springer. https://doi.org/10.1007/978-3-319-31686-4 6

Uvin, P., Jain, P. S., \& Brown, D. L. (2000). Think large and act small: Toward a new paradigm for NGO scaling up. World Development, 28(8), 1409-1419. https://doi.org/10.1016/S0305-750X(00)00037-1

Walker, K. (2016, July 12). 3D-printed weather stations help rural Zambian communities. Design Indaba. http://www.designindaba.com/articles/creative-work/3d-printedweather-stations-help-rural-zambian-communities

World Intellectual Property Organisation (WIPO). (2015). World intellectual property report: Breakthrough innovation and economic growth. https://www.wipo.int/edocs/pubdocs/ en/wipo pub 944 2015.pdf

Zahra, A. S., Gedajlovic, E., Neubaum, D. O., \& Shulman, J. M. (2009). A typology of social entrepreneurs: Motives, search processes and ethical challenges. Journal of Business Venturing, 24(5), 519-532. https://doi.org/10.1016/j.jbusvent.2008.04.007

\section{Research intervierws}

Interviewee 1. Representative of CDI. Interviewed in-person, 23 February 2017.

Interviewee 2. Representative of North West FabLab. Interviewed via phone, 6 April 2017.

Interviewee 3. Representative of FabLab Bloemfontein. Interviewed via phone, 6 April 2017.

Interviewee 4. Representative of Ekurhuleni FabLabs. Interviewed via phone, 6 April 2017.

Interviewee 5. Representative of Sebokeng FabLab. Interviewed via Skype, 7 April 2017.

Interviewee 6. Representative of Limpopo FabLab. Interviewed via phone, 19 April 2017.

Interviewee 7. Representative of eKasi Labs. Interviewed via phone, 15 May 2017.

Interviewee 8. Representative of AB3D and Happy Feet. Interviewed in-person, 4 July 2017.

Interviewee 9. Representative of FabLab Nairobi. Interviewed in-person, 5 July 2017.

Interviewee 10. Representative of FabLab Nairobi. Interviewed in-person, 5 July 2017.

Interviewee 11. Representative of AB3D and Artisan Hive. Interviewed in-person, 5 July 2017.

Interviewee 12. Representative of eKasi Labs. Interviewed via phone, 12 July 2017.

Interviewee 13. Representative of MedTech Kijenzi. Interviewed via Skype, 30 August 2017. 